\title{
WHY FUNCTIONAL DISCOURSE GRAMMAR IS NOT, AND COULD NOT BE, A DISCOURSE GRAMMAR
}

\author{
J. Lachlan Mackenzie \\ VU Amsterdam
}

\begin{abstract}
This article begins by tracing the debate within Functional Grammar (FG), to which José Gómez Soliño was a contributor, on the role of discourse in that model. That debate ultimately gave rise to Functional Discourse Grammar (FDG) as a grammar of the Discourse Act. Discourse Acts group into Moves, but attempts to circumscribe the Move grammatically have not been successful, and FDG has focused on phenomena that occur within the Discourse Act and between Discourse Acts. Reviving Dik's model of verbal interaction, the article goes on to interpret FDG as a tool for the realization of the speaker's and hearer's communicative strategies as they seek a certain meeting of minds through the use of language. The article concludes by asserting that FDG is not a grammar of discourse, nor could it be.
\end{abstract}

KeYwords: Functional Grammar, Functional Discourse Grammar, Discourse Act, strategy, discourse.

\section{POR QUÉ LA GRAMÁTICA DISCURSIVO-FUNCTIONAL NO ES, NI PODRÍA SER, UNA GRAMÁTICA DEL DISCURSO}

\section{RESUMEN}

Este artículo hace un seguimiento del debate sobre el papel del discurso dentro de la Gramática Funcional (GF), debate al que José Gómez Soliño ha contribuido, y que acabó dando lugar a la Gramática Discursivo-Funcional (GDF) como gramática del Acto Discursivo. Los Actos Discursivos se agrupan en Intervenciones (Moves), pero los intentos de circunscribir las mismas gramaticalmente no tuvieron éxito, y por tanto la GDF se ha centrado principalmente en los fenómenos que ocurren tanto dentro de un Acto Discursivo como entre distintos Actos Discursivos. Reavivando el modelo de interacción verbal de Dik, el artículo interpreta la GDF como una herramienta para la comprensión de las estrategias comunicativas de emisores y receptores que buscan un cierto encuentro de mentes a través del uso del lenguaje. El artículo concluye afirmando que la GDF no es una gramática del discurso, ni jamás podría serlo.

Palabras clave: Gramática Funcional, Gramática Discursivo-Funcional, Acto Discursivo, estrategia, discurso.

DOI: https://doi.org/10.25145/j.recaesin.2020.80.05

Revista Canaria de Estudios Ingleses, 80; April 2020, pp. 73-87; ISSN: e-2530-8335 


\section{INTRODUCTION}

José Gómez Soliño, in addition to his countless other achievements, was for several years an active and creative contributor to Simon C. Dik's Functional Grammar (FG; Dik Theory of Functional Grammar, Theory of Functional Grammar. Parts 1 and 2), especially in the nineties of last century, when he was teaching FG at the University of La Laguna, writing articles (notably Gómez Soliño "Texto y Contexto", "Organización Jerárquica") and inspiring his pupils, not least the guest editor of this volume, to embrace a lifelong commitment to the further development of the theory. The major years of José's involvement with FG corresponded with the premature illness and death of Simon Dik ( $\$ 1995)$, a time that was not only emotionally difficult for the international band of adherents of the theory but also one of great doubts: could FG continue without its intellectual father? if so, what direction should it take? Inevitably, Simon had left behind not only a rich library of publications but also a number of more inchoate ideas, many of which found their way in more developed form into Dik (Theory of Functional Grammar. Parts 1 and 2), edited by his doctoral student, colleague and ultimate successor, Kees Hengeveld. In this period of flux, the question that was predominant in the workshops and conferences of those years concerned the role of discourse in FG. After all, had Simon not written that "the highest aim of a functional grammar of a particular language is to give a complete and adequate account of the grammatical organization of connected discourse in that language" (Dik Theory of Functional Grammar. Part 1 12)? This was the very question to which José made the most important and lasting of his contributions - contributions that were to feed into the emergence of a successor theory to FG, Functional Discourse Grammar (FDG; Hengeveld and Mackenzie Functional Discourse Grammar).

FG, as originally conceived by Dik (Functional Grammar), was first and foremost a grammar of the clause. In understanding this, it should be borne in mind that FG arose in the context of the emergence of various other grammars of the clause (or 'sentence'), not least Generative Grammar, but also Generative Semantics with its quasi-logical representations, Case Grammar, Relational Grammar and many others, and at that time Dik saw himself as working with several of the same presuppositions as those rivalling theories (Mackenzie "First History"). This focus on clause grammar was also apparent in Dik's work on the computational implementation of FG (Functional Grammar in PROLOG). The later push towards the inclusion of discourse considerations in FG arose from a number of factors: (a) functionally oriented linguists across the world were increasingly turning to the analysis of discourse and its interface with grammar (M.A.K. Halliday, Wallace Chafe, Talmy Givón, Sandra Thompson and many others); (b) in the application of FG, it was becoming ever more apparent that numerous properties of clausal grammar (anaphora, focus, extra-clausal constituents, sentence type, etc.) could not be fully understood without reference to the discourse context; (c) most of the practitioners of FG at that time were not linguists pur sang but teacher-researchers in departments of foreign languages whose daily work confronted them with both grammar and textuality (e.g. Co Vet [French], Casper de Groot [Hungarian], 
Jadranka Gvozdanović [Serbo-Croat-Bosnian], Kees Hengeveld [Spanish], and Mike Hannay, myself and José Gómez Soliño [English]); and (d) the FG group included the forceful presence of classicists ${ }^{1}$ like Machtelt Bolkestein, Harm Pinkster, Caroline Kroon and Albert Rijksbaron, whose corpora of Latin and Greek texts were by definition textual and increasingly consultable via computer concordance programs. More generally, the rise of corpus linguistics was also enticing FG linguists away from Dik's practices of using introspective data and invented pseudo-English sentences to elucidate theoretical points towards the consultation and analysis of attested material, i.e. written texts or transcriptions of oral performance.

This shift towards the discursive came to dominate the debates of the nineteen-nineties in the international FG community. Some maintained that discourse is essentially a dynamic process occurring in time while grammar describes the product of linguistic activity and that the two were therefore incommensurable. Grammar may have developed as a highly suitable tool for understanding the results of discourse production, and the influence of discourse factors may be detectable in language users' grammatical choices, but the two domains could not be collapsed into a single theory. Others took the view that the products of discursive activity (those written texts and transcriptions that were now readily available in corpora) could and should be analysed in ways that were analogous to the FG analysis of individual sentences. The layers that had come to be the hallmark of Dik's presentation of the theory (Theory of Functional Grammar) could, it was argued, be extended upwards into the domain of discourse, allowing FG to encompass discourse without doing any injury to its inner consistency. Among the major exponents of this view were Kees Hengeveld ("Cohesion"), Ahmed Moutaouakil ("On the Layering"), and -as we shall see below- José Gómez Soliño ("Texto y Contexto", "Organización Jerárquica"); Dik's posthumous work (Theory of Functional Grammar. Part 2) also suggests an endorsement of this position.

The debate was to be resolved in 2000, when Kees Hengeveld proposed a new model (published as Hengeveld "The Architecture") in which both sides could find enough of their commitments reflected. This model -dubbed Functional Discourse Grammar to reconcile the opposing views- retained the FG notion that discourse could be analysed using a system of layers with a full arsenal of operators, restrictors and modifiers, while also separating 'discourse' from 'grammar' by instituting three levels of analysis, an Interpersonal Level for 'pragmatics and rhetoric', a Representational Level for 'semantics' and an Expression Level for 'morphosyntax'. This new model did not spring like Athena from the brow of Zeus but had its roots in the vibrant discussions of the preceding years and notably in the work of José Gómez Soliño. The purpose of this brief contribution to José's richly deserved homenaje is to trace the lines of connection between his thinking and FDG as currently constituted

1 Simon Dik was himself a classicist by training.

2 The Expression Level was later to be divided into Morphosyntactic and Phonological Levels. 
and practised. In particular, my aim is to argue that despite its full name, FDG is not, and could not be, a 'discourse grammar."

Section 2 will present FDG as a grammar of the Discourse Act, showing the advantages of limiting the framework in this way. Section 3 revives Dik's model of verbal interaction in order to situate an understanding of verbal interaction as strategic and of grammar as a tool for attaining one's strategic goals. The paper ends with a brief conclusion.

\section{FDG: A GRAMMAR OF THE DISCOURSE ACT}

In essence, while FG was a grammar of the clause, FDG (Hengeveld and Mackenzie Functional Discourse Grammar) is a grammar of the Discourse Act. Discourse is seen as actional in nature, the result of one human being's expenditure of energy in an effort to communicate thoughts, feelings, requests, warnings, etc. to other human beings. This overall activity is divided into Discourse Acts: many are expressed as clauses, but they may just as well show up as a non-clausal succession of phrases, a single phrase, a single word or a combination of clauses.

The Discourse Act (symbolized as $A_{1}$ ) is the central concept of the Interpersonal Level of analysis within FDG. The inner structure of $A_{1}$ contains four elements, all of which are prefigured in Gómez Soliño ("Organización Jerárquica" 52-53):

An indication of the type of Illocution $\left(\mathrm{F}_{1}\right)$

A variable identifying the Speaker $\left(\mathrm{P}_{1}\right)_{S}$

A variable identifying the Addressee $\left(\mathrm{P}_{2}\right)_{\mathrm{A}}$

The Communicated Content $\left(\mathrm{C}_{1}\right)$

A defining principle of FDG is that elements are specified in the analysis only if they have some consequences for the form in which a Discourse Act is expressed. Clearly, every $A_{1}$ contains an Illocution defining the type of speech act to be encoded (distinguished in morphosyntactic and/or phonological structure), and no $\mathrm{A}_{1}$ lacks at least some communicated content. As for the necessity of including the speech participants in $\left(\mathrm{A}_{1}\right)$, Gómez Soliño ("Organización Jerárquica" 53) gives an example from Spanish ¿Está cansada? 'Are you tired?', arguing that here "a user of Spanish is carrying out an interrogative act the ultimate form of which is affected by the fact that the function of addressee is performed by a woman with respect to whom the speaker does not adopt an equal position"; ${ }^{4}$ in other words, translated into the FDG

3 The translation frequently employed in Spanish, 'Gramática Funcional del Discurso', is therefore misleading and should be avoided.

4 "un usuario del espańol realiza un acto interrogativo cuya forma final está condicionada por el hecho de que la función de receptor está desempeñada por una mujer respecto de la cual quien desempeńa el rol emisor no se muestra en un plano de igualdad" 
formalism, the presence of the third person form esta and the feminine form cansada can only be explained by including the respective variables in the grammar, with $\mathrm{P}_{\mathrm{I}}$, the Addressee, being marked as 'high' and 'female', alongside the indication of the interrogative illocution:

$$
\left(A_{\mathrm{I}}:\left[\left(\mathrm{F}_{\mathrm{I}}: \operatorname{INTER}\left(\mathrm{F}_{\mathrm{I}}\right)\right)\left(\mathrm{P}_{\mathrm{I}}\right)_{\mathrm{S}}\left(\mathrm{hf} \mathrm{P}_{\mathrm{J}}\right)_{\mathrm{A}}\left(\mathrm{C}_{\mathrm{I}}\right)\right]\left(\mathrm{A}_{\mathrm{I}}\right)\right)
$$

The Communicated Content, in keeping with the Interpersonal Level as a whole, is actional in nature and consists of a series of Subacts, i.e. the mini-acts of reference and predication (or 'ascription') carried out in the performance of a Discourse Act. It is here that the 'pragmatic functions' of Topic and Focus are located; again, these are assigned only where there is some formal feature of the unit under analysis, be it morphosyntactic or phonological (or both), that needs to be accounted for.

Of particular interest in the present context is the question of possible layers of analysis higher than $A_{1}$. FDG has adopted the position that Discourse Acts group into Moves $\left(\mathrm{M}_{1}\right)$ :

$$
\left(M_{1}:\left[\left(A_{1}\right) \ldots\left(A_{n}\right)\right]\left(M_{1}\right)\right)
$$

This proposal develops work in the mid-nineties by Caroline Kroon (Discourse Particles), who -herself drawing on Eddy Roulet's notion of intervention (see Roulet, Filliettaz and Grobet Un Modèle for a comprehensive presentation)proposed the use of the term Move for an autonomous contribution to an ongoing interaction. The expression movimiento is also used by Gómez Soliño ("Organización Jerárquica" 57) for the unit expressed as a 'text block' (bloque textual), but he sees the Move as a representational rather than interpersonal unit. These text blocks are themselves part of larger 'text frames' (marcos textuales), which in turn form part of textualizaciones; these nested layers form part of his vision of text and discourse as thoroughly hierarchical. FDG differs, as we shall see, in taking the Move as the highest layer of grammatical interest.

In dialogue, a Move either opens up the possibility of a reaction (an Initiation Move) or is itself a reaction (a Reaction Move). Thus a question-answer sequence, or a greeting and response pair, counts as a succession of Initiation and Reaction Moves. So far so good, but in practice, it has proved difficult to find precise and conclusive evidence for the demarcation of Moves, especially in more protracted texts, since they have been defined functionally, in terms of their occurrence in dialogue, rather than formally. It has not been possible to identify fully reliable morphosyntactic or phonological clues to their presence. Hengeveld and Mackenzie (Functional Discourse Grammar) and Keizer (A Functional Discourse Grammar for English) do suggest various pointers to Move status: (a) expression as an Utterance $\left(\mathrm{U}_{1}\right)$ ending with a falling intonation (Hengeveld and Mackenzie 51); (b) the insertion of so to indicate a return to the main line of a narrative after an interruption to provide background information (51-52), of by the way to introduce a digressive Move (Keizer 49) or of in sum to introduce a summarizing Move (50); (c) the use of expressions 
like to cut a long story short to introduce a Move that rounds off a story (Hengeveld and Mackenzie 59); (d) the deployment of 'grammatical elements' like however to introduce a contrasting Move (59-60); (e) the domain of reflexivity in Lezgian (373); ${ }^{5}$ (f) the use of paratones; (g) the possibility, in English, of reducing two Moves to one phonologically by 'flapping' an Utterance-final / $\mathrm{t}$ / as / $\mathrm{r} /$ (431). Although these criteria make intuitive sense, they are indeed no more than pointers or tendencies. None of these phenomena are necessarily present, and none are necessarily distinctive of Moves as opposed to Discourse Acts or, possibly, larger stretches of discourse. After all, not all Moves have a falling intonation (most questions do not, for example), and nor do all have paratones (as is conceded by Hengeveld and Mackenzie Functional Discourse Grammar 430); however could just as well link two Discourse Acts (60), as could /t/-flapping; the markers so, by the way, in sum and even to cut a long story short could all precede a discourse span much longer than could be reasonably regarded as a Move; and finally, although the observation about Lezgian reflexives is intriguing, it clearly could only be generalized -if it is verified- to the few languages that have interpersonal triggering of reflexivity. ${ }^{6}$

The conclusion must be, then, that to date no reliable formal correlate has been found of the Move, "the largest unit of interaction relevant to grammatical analysis" (Hengeveld and Mackenzie Functional Discourse Grammar 50). Does this mean that the Move should (at least provisionally) be consigned to the scrapheap of discarded grammatical concepts? I believe it does not. Rather, the Move should continue to be recognized as the domain within which the relations among its constituent Discourse Acts are examined and defined, and this proposal aligns strongly with the presentation in Hengeveld and Mackenzie (Functional Discourse Grammar), where the most frequent collocates of 'Move' are in, within and contains; i.e., the Move serves to define the upper limit of FDG's concerns. This in turn reflects the fact that FDG, as its name indicates, is a grammar, and more specifically a grammar of the Discourse Act. A Functional Discourse Grammar is therefore concerned with both the internal properties of the Discourse Act (i.e. everything that lies inside the scope of the $A_{1}$ variable) and its external properties (i.e. the relations among the Discourse Acts in the set $\left\{\left(\mathrm{A}_{1}\right) \ldots\left(\mathrm{A}_{\mathrm{n}}\right)\right\}$ that lies within -and in technical terms 'restricts' - the $\left(M_{1}\right)$ variable).

The goal of FDG is thus not to attempt an analysis of units larger than the single Move. Such attempts, it should be said, were made in the FG framework, as we have seen in the proposals of Gómez Soliño ("Texto y Contexto", "Organización Jerárquica") and notably in the final chapter of Dik (Theory of Functional Grammar. Part 2 409-441), significantly titled 'Towards a functional grammar of discourse'.

5 See Dik (Theory of Functional Grammar. Part 2 421) for a similar case pertaining to the scope of reflexives in Latin.

${ }_{6}$ Moreover, the long-distance reflexive in the Lezgian example (329) in Hengeveld and Mackenzie (Functional Discourse Grammar 373) occurs within the frame of indirect speech, suggesting that the domain within which reflexivity holds may in fact be a Propositional Content (i.e. a representational rather than interpersonal grouping). 
There, in the course of setting out "the bare outlines of what a theory of discourse should look like" (409) and in keeping with achieving the "highest aim" cited in Section 1, Dik considers two types of discourse that are consciously structured by language users: the job interview and the story. The former is structured as a set of "boxes within boxes within boxes" (424) -[Opening rituals [Procedure [State of knowledge [Exchange of information] State of Knowledge] Procedure] Farewell Rituals] - in a manner that is reminiscent of grammatical organization. However, we should not be fooled into thinking that this nesting structure is any more than a topdown administrative measure introduced to bring order, efficiency and comparability rather than being in any sense a reflection of human communicative strategies. If anything, this structure is applied by committee chairs to prevent job interviews from falling prey to the usual incremental, one-thing-leads-to-another sequencing of normal conversation that is the natural object of discourse-grammatical inquiry. Dik's other example (Theory of Functional Grammar. Part 2 430-431), which is analogous to Gómez Soliño's ("Organización Jerárquica" 64-66) treatment of an oral narrative, is concerned with the seven-stage structure of narratives as Opening Abstract - Orientation - Events and Evaluation - Resolution - Epilogue - Closing. However, this structure was induced from data by various analysts (notably Labov and Waletzky "Narrative Analysis"), but without any claim to being a hypothesis about permissible and impermissible stories. In addition, this proposal strays very far from grammar in the sense that the formal consequences of the various 'episodes' of the structure, if any, are at best optional. As Philip N. Johnson-Laird said of similar 'story grammars', "no story grammarian has ever formulated an effective procedure for determining the membership of such categories" (Mental Models 362). Gómez Soliño ("Organización Jerárquica" 66), too, in pursuit of persuading his readers that discourse is structured hierarchically like grammar, invites them to consider the use of discourse markers, tenses, direct speech, proper names and pronouns, as well as lexical patterns, but these disparate phenomena (if present) are still far from constituting a grammar of discourse. And when it comes to conversational interaction, the natural area of human verbal exchange, the point about reducing discourse to grammar is made most effectively in the following words of Stephen C. Levinson:

Interaction is characterized by action chains and sequences [...] governed not by rule but by expectation. Thus, there is an assumption that a question expects an answer, but there is no rule that a question must be followed by an answer. [...] The outcome of a momentary interaction is something none of the parties can plan in advance-it is a contingent product. That is why there is no such thing as a formal grammar of discourse. (Levinson "On the Human" 45-46; my emphasis) 


\section{A STRATEGIC VIEW OF FDG}

The "contingent product" referred to by Levinson occurs, as Gómez Soliño ("Organización Jerárquica" 44) points out, within a dialogic situation. The dialogicality of communication has played a significant role in the recent development of FDG (cf. Mackenzie "Dynamicity and Dialogue") alongside, and to some extent in rivalry with, the speaker-oriented view articulated in the initial pages of Hengeveld and Mackenzie (Functional Discourse Grammar 1-2): "a model of grammar will be more effective the more its organization resembles language processing in the individual". This latter, 'orthodox' view has favoured a unidirectional derivational interpretation of FDG as modelling a succession of operations: the sequence starts with the speaker's pre-linguistic cognitive activity and communicative intention (modelled in the Conceptual Component), followed by the speaker's operations of formulation and encoding in the Grammatical Component (with input from the Contextual Component), leading ultimately to the phonetic, graphic or possibly gestural articulation in the Output Component (Hengeveld and Mackenzie Functional Discourse Grammar 6). The alternative dialogical view brings Dik's (Theory of Functional Grammar. Part 1) perspective back into play, one that emphasizes the strategic nature of linguistic communication. It is summarized by Gómez Soliño (“Organización Jerárquica” 45) in Figure 1.

Figure 1 represents the speaker (emisor) and the hearer (receptor) at some moment in a dialogue. What they share is the code (código), i.e. they both have the ability to use a shared language actively and passively, and the environment (medio), i.e. the communicative situation in which they find themselves. What they do not share is their individual stores of 'pragmatic information' (información pragmática), which are entirely personal and cover the totality of knowledge, beliefs, preconceptions, feelings, etc. that together constitute the mind of an interactant at a particular moment. From this perspective, linguistic communication is an attempt by language users to bridge the gap between their minds, exploiting their shared linguistic competence and awareness of their situation. Given a particular intention, the speaker performs a Discourse Act, formulating and encoding their ideas in such a way that the resultant Utterance has a reasonable chance of effecting the desired change in the pragmatic information of the receiver. The latter, in decoding the Utterance, then attempts to reconstruct the presumed communicative intention of the speaker. In other words, the speaker anticipates (anticipación) the hearer's reconstruction (reconstrucción) of the Utterance (expresión lingüistica).

What this means is that the form of words chosen by the speaker to perform the Discourse Act contributes to, but does not dictate, the interpretation; the speaker's words are not a complete verbalization of their communicative intention, not least because of the omnipresence of motivations additional to the mere conveyance of knowledge, such as the desire to remain polite; and the information decoded by the hearer forms only part of the significance they will derive from the utterance, a significance which will, for example, also contain elements of the hearer's evaluation of the speaker. The Discourse Act is therefore said to be underdetermined, i.e. its 


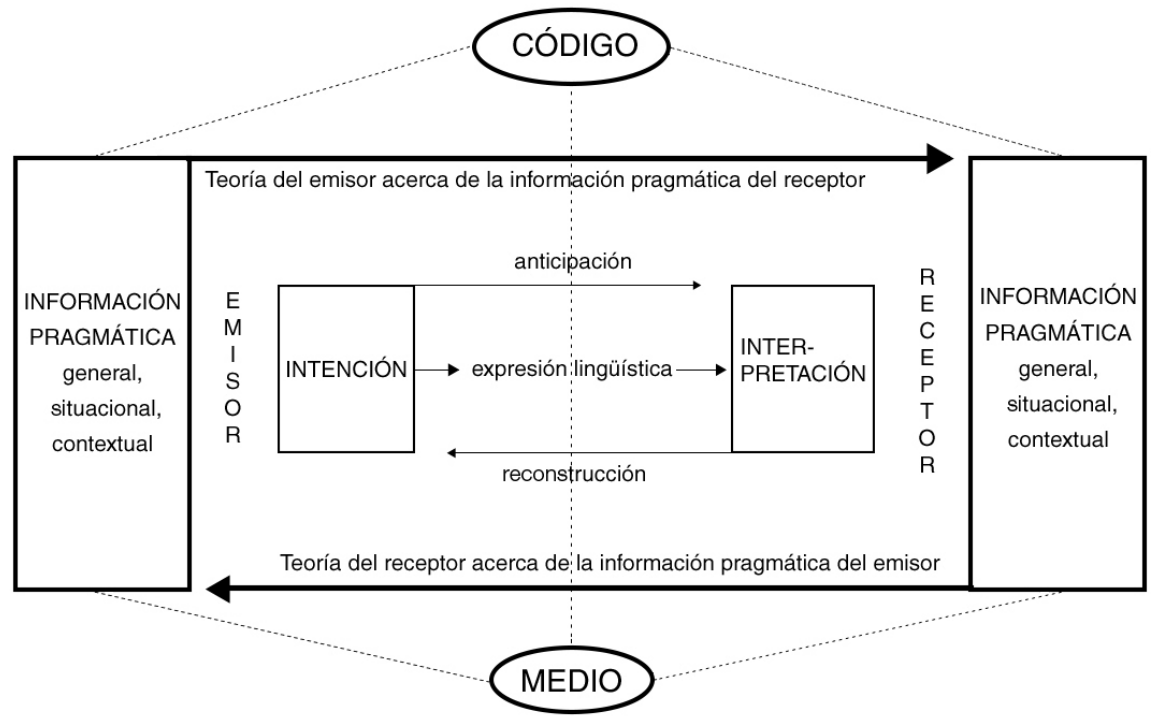

Figure 1: Dik's model of dialogical interaction as diagrammed by Gómez Soliño (“Organización Jerárquica” 45).

content is very much less than its total import, but it is also an essential trigger of that import. ${ }^{7}$

The import of a Discourse Act cannot generally be deduced or induced from the result of decoding; rather, as Randy J. LaPolla has argued, the kind of reasoning used is abductive ("On the Logical Necessity"), a form of reasoning that we use to make sense of our perceptions. For example, if we observe that the streets are wet, we may abduce that it has been raining. Note that a characteristic of our abductive abilities is that we may be wrong: the streets may for example be wet because they have newly been hosed down in the fashion common in many Spanish towns. In dialogue, too, the hearer is using clues to try and make sense of what the speaker has said, through the process of reconstruction mentioned in Figure 1; the functional properties of the utterance are among the most salient of these clues. Consider the following mini-interaction:

(3) A: I'd like to invite you to have dinner with me.

B: Unfortunately I have promised to visit my Aunt Rose tonight.

7 Thom Scott-Philipps ("Nonhuman Primate Communication") argues that all animal (including human) communication advances in this way; the only exception is 'quorum sensing' among bacterial cells. 
The decoding of this simple pair of Moves is relatively straightforward. Nevertheless, it does involve various abductive inferences on the part of A and B:

(a) I'd like to - this is formulated as a conditional, but B will probably infer that no conditionality is actually intended.

(b) invite - this typically connotes that A is willing to pay, but is B necessarily to infer that this will be the case, and how does B feel about that?

(c) you - this is a clear instance of underdetermination in English, which lacks the Spanish tú vs.vosotr@s distinction; is A to infer that his or her life partner is also invited or not?

(d) have dinner with me - this literally means 'consume an evening meal together', but does A maybe have more in mind?

(e) A makes no mention of the time, but B clearly infers from the situation that A means 'tonight'.

(f) I have promised to visit my Aunt Rose tonight-B's response apparently has nothing to do with having dinner with A, but given shared social knowledge about the timing of dinner, promises, family commitments and possibly the role of 'white lies' in conversation, A can abduce that B is turning him/her down. There is a clue to this inference in the adverb Unfortunately, which may be an expression of B's displeasure at having made a commitment to visit an aunt or their regret at being unable to accept the invitation, or simply a politeness marker softening the blow for A - A can only guess! Another clue may be found in B's inclusion of tonight, which makes their inference (e) explicit but also could leave open the possibility of other evenings, especially if contrastive intonation is used on this word.

The role of grammar, from this perspective, is to facilitate strategic interplay in dialogue. One property of utterance production and interpretation that has received some attention in FDG is its incrementality (Hengeveld and Mackenzie Functional Discourse Grammar 24): the process of 'making sense' (the inferential process) is not postponed until the utterance is complete, and the speaker knows this too, and various properties of FDG, notably the 'depth first' principle that enforces encoding of material as soon as possible, reflects this fact. Another property of abductive inference is that it involves guesswork, as we have seen. Hearers also make guesses about how an incomplete utterance will continue and end, and they may even interrupt the speaker if they are confident about those guesses. This, too, has found its way into FDG in the countdown to $\mathrm{P}^{\mathrm{F}}$, the final position in a morphosyntactic unit (Mackenzie "Dynamicity and Dialogue" 67-69). Many grammatical properties of informal dialogical interaction are understandable in the framework of sensitivity to the real-time production and interpretation of utterances: the division of speech into relatively short Discourse Acts, with various preparatory and corrective Acts; the initial position of Topic elements which limit the hearer's search space; the signalling function of anticipatory elements like English $i t$, often associated with extraposition; 
and the prominence given to contrastive elements by clefting, which restricts the contexts within the hearer can make sense of what is being said.

Alongside such pragmatically inspired grammatical options as topicalization, extraposition, and clefting, there are also hard and fast rules, especially in a rather syntactically rigid language like English. LaPolla ("Why Languages Differ" 131), comparing English and Chinese, observes a contrast which applies analogously between English and Spanish:

(a) The man dropped the watermelon and burst.

(b) El hombre dejó caer la sandía y estalló.

In Spanish the unexpressed subject of the second coordinated clause could be either the man (el hombre) or the watermelon (la sandía), but the speaker is likely to have intended that the latter burst; this is an inference that the speaker will expect the hearer to make. In English, by contrast, there is an inviolable rule that the subjects of two coordinated clauses must be identical unless a different subject is specified in the second clause: (5a) can therefore only mean that the man burst, and the hearer has no freedom to infer anything else. LaPolla regards such grammatical rules as "constraints on interpretation" (122-123), i.e. their functionality resides in limiting the abductive inferences that the hearer is permitted to make.

The view of a grammar that emerges from this perspective is that of an instrument, an intricate tool that language users deploy in order to bridge the differences between their individualities. This entails that the two representations of meaning that characterize the FDG analysis of a Discourse Act, the pragmatic meaning shown at the Interpersonal Level and the semantic meaning shown at the Representational Level, do not replicate the speaker's conceptualization or even their communicative intention but rather are created as part of a strategic 'campaign' to have the desired effect on the hearer. For instance, a Subact is never inherently a Topic, but may be treated as one as part of the speaker's communicative strategy; a request is never inherently an Interrogative Illocution, but again may be treated as one in an indirect speech act strategy.

This strategic approach has been very effectively examined and applied by Mike Hannay and Caroline Kroon ("Acts and the Relationship"). After a detailed demonstration of the fact that a Discourse Act need not correspond to a syntactic clause, they argue that it is a matter of the speaker's "strategic planning" (104) how their ideational material is chunked into Discourse Acts, distinguishing those that are substantive (referential and/or ascriptive) and those that are regulatory (like let me see or $\left.y^{\prime} k n o w\right)$. They go on to show that the most reliable clues to Discourse Act status are prosodic divisions (with a loose relation to punctuation) and contend that what distinguishes (6c) from (6a) and (6b) is how the speaker strategically divides the message into Discourse Acts:

(6) (a) He waited, for ages.

(b) He waited. For ages.

(c) He waited for ages. 
In (6a) and (6b), Move $\left(M_{\mathrm{I}}\right)$ is divided into two Discourse Acts, the second being an elaboration of the first - the punctuation difference is seen as relatively insignificant - while in $(6 \mathrm{c})\left(\mathrm{M}_{\mathrm{I}}\right)$ consists of a single Discourse Act. The contrast is, in Hannay and Kroon's terms, not one of ideas, but of acts:

$$
\begin{array}{ll}
\text { (a) }\left(\mathrm{M}_{\mathrm{I}}:\left[\left(\mathrm{A}_{\mathrm{I}}\right)\left(\mathrm{A}_{\mathrm{J}}\right)_{\text {Elab }}\right]\left(\mathrm{M}_{\mathrm{I}}\right)\right) & (=(6 \mathrm{a}),(6 \mathrm{~b})) \\
\text { (b) }\left(\mathrm{M}_{\mathrm{I}}:\left(\mathrm{A}_{\mathrm{I}}\right)\left(\mathrm{M}_{\mathrm{I}}\right)\right) & (=(6 \mathrm{c}))^{8}
\end{array}
$$

An important implication of this strategic view of FDG is that there is no direct flow between our conceptualization processes and the formulation of Discourse Acts, since the latter operation is the result of the speaker's strategic planning. As mentioned above, the workings of the grammatical component are triggered by a Conceptual Component, which in many ways is a continuation of Dik's notion of pragmatic information. For Hannay and Kroon, it is in this pre-grammatical component that speaker develops both their ideas and their strategies for conveying them, for example by dividing an idea over two or more Acts or by combining two or more ideas into a single Act. The question has arisen among practitioners of FDG whether it is the grammarian's job to represent these ideas and strategies. John $\mathrm{H}$. Connolly ("Conceptual Representation") has argued in favour of doing so, proposing ways of reverse-engineering a conceptual representation from the Interpersonal and Representational Levels. Others (Hengeveld and Mackenzie "Reflections on the Lexicon") have defended the view that this is neither desirable nor achievable.

The debate can be framed in terms of Levinson's distinction between A-theorists and B-theorists ("From Outer to Inner" 14): the former equate semantic structure and conceptualization and are strongly identified with cognitive linguistics, while the latter, with whom Levinson sympathizes, argue that thought and meaning must be sharply distinguished. He mentions a number of points made by B-theorists (16ff.): (a) the existence of lexical gaps, even of entire lexical fields that are absent, for many realms of experience cannot be expressed in language; (b) the multiple discoveries made by (post-)Gricean pragmatics showing that we very often do not say what we mean; (c) the ubiquity of deixis in our languages (consider almost all the elements in I am going to the local airport tonight); (d) the way language forces us to take a perspective on our thinking; and many others. Levinson's conclusion is obvious (23): language is public, while thought is private, and individual. A corollary of the private, individual status of thought is that it differs from one person to the next; as Robert Epstein wrote in a recent essay ("The Empty Brain"), "there is no reason to believe that any two of us are changed the same way by the same experience" (emphasis his), giving the example of two people's reactions to attending the same concert. For FDG, which is clearly a B-theory in Levinson's terms, the implication

${ }^{8}$ At the Phonological Level, (6a) and (6b) will be analysed as an Utterance (U $\mathrm{U}_{\mathrm{r}}$ ) containing two Intonational Phrases (IP $)$ and (IP $)$, or (6b) possibly as two utterances $\left(\mathrm{U}_{\mathrm{I}}\right)$ and $\left(\mathrm{U}_{\mathrm{J}}\right)$. (6C) will form a single Utterance with a single Intonational Phrase. 
is that grammarians need to focus on the publicly available phenomena of language in order to understand how it works as a strategic device.

\section{CONCLUSION}

In concluding, let us consider the repercussions of the preceding argument for FDG's stance with respect to the analysis of discourse. It will be clear that the original motivation for developing the theory was bound up with the observation that many grammatical phenomena can only be fully understood in their discourse context. In (8B) he and him are in generative grammar said to be "free" (unlike reflexive pronouns, which are "bound"), but in FDG they must be linked to their antecedents in (8A):

(8) A: What does John think about Bill?

B: He likes him.

The grammar must contain co-indexing mechanisms that link he to John and him to Bill, but this is far from forming a complete account of the minidiscourse in (8). B's answer is, like all utterances, strategic. As a grammarian, one can only speculate why B says so little or why he/she uses a mildly positive verb, but as an interactant, A will notice this and interpret B's utterance in terms of A's own pragmatic information and their assumptions about B's pragmatic information. This is the kind of 'discourse analysis' that we all carry out constantly every day, but looking on from the outside, as it were, the grammarian has nothing to add except observations about cohesive links, shifts of tense, discourse markers, evidentials, etc. These observations are essential to the academic discipline of discourse analysis but they do not add up to a grammar in the way that FDG does aspire to provide a complete account of the internal properties of Discourse Acts and their interrelations within the Move. For that reason, FDG is not, and indeed could not be, a grammar of discourse. 


\section{WORKS CITED}

Connolly, John H. "Conceptual Representation and Formulation: A Computationally Oriented Approach." Casebook in Functional Discourse Grammar. Ed. J. Lachlan Mackenzie and Hella Olbertz. Amsterdam: John Benjamins, 2013. 125-153.

Dik, Simon C. Functional Grammar. Amsterdam: Noord-Holland, 1978.

Diк, Simon C. The Theory of Functional Grammar. Part 1. Dordrecht: Foris, 1989.

Dik, Simon C. Functional Grammar in PROLOG: An Integrated Implementation for English, French and Dutch. Berlin: Mouton de Gruyter, 1992.

Dik, Simon C. The Theory of Functional Grammar. Part 1. Ed. Kees Hengeveld. Berlin: Mouton de Gruyter, 1997a.

Dik, Simon C. The Theory of Functional Grammar. Part 2. Ed. Kees Hengeveld. Berlin: Mouton de Gruyter, 1997b.

Epstein, Robert. "The Empty Brain.” Aeon. Web <https://aeon.co/essays/your-brain-does-not-process-information-and-it-is-not-a-computer>

Gómez Soliño, José. “Texto y Contexto en la Teoría de la Gramática Funcional.” Revista de Lenguas para Fines Especificos 2 (1995): 201-216.

Gómez Soliño, José. “La Organización Jerárquica de los Textos desde una Perspectiva Funcional.” Os Estudios Ingleses no Contexto das Novas Tendencias. Ed. María Teresa Caneda Cabrera and Javier Pérez Guerra. Vigo: Universidade de Vigo, 1996. 42-68.

Hannay, Mike, and Caroline Kroon. "Acts and the Relationship between Discourse and Grammar". Functions of Language 12:1 (2005), 87-124.

Hengeveld, Kees. "Cohesion in Functional Grammar." Discourse and Pragmatics in Functional Grammar. Ed. Christopher S. Butler, John H. Connolly, Richard A. Gatward and Roel M. Vismans. Berlin: Mouton de Gruyter, 1997. 1-16.

Hengeveld, Kees. “The Architecture of a Functional Discourse Grammar." A New Architecture for Functional Grammar. Ed. J. Lachlan Mackenzie and María Á. Gómez-González. Berlin: Mouton de Gruyter, 2004. 1-21.

Hengeveld, Kees, and J. Lachlan Mackenzie. Functional Discourse Grammar: A Typologically-Based Theory of Language Structure. Oxford: Oxford UP, 2008.

Hengeveld, Kees, and J. Lachlan Mackenzie. "Reflections on the Lexicon in Functional Discourse Grammar.”. Linguistics 54.5 (2016): 1135-1161.

Johnson-Laird, Philip N. Mental Models: Towards a Cognitive Science of Language, Inference and Consciousness. Cambridge: CUP, 1983.

KeIzer, Evelien. A Functional Discourse Grammar for English. Oxford: Oxford UP, 2015.

Kroon, Caroline. Discourse Particles in Latin: A Study of nam, enim, autem, vero and at. Amsterdam: Gieben, 1995.

Labov, William, and Joshua Waletzy. "Narrative Analysis." Essays on the Verbal and Visual Arts. Ed. June Helm. Seattle: University of Washington Press, 1967. 12-44.

LaPolla, Randy J. "Why Languages Differ: Variation in the Conventionalisation of Constraints on Inference." Language Variation: Papers on Variation and Changes in the Sinosphere and 
in the Indosphere in Honour of James A. Matisoff. Ed. David Bradley, Randy J. LaPolla, Boyd Michailovsky and Graham Thurgood. Canberra: Pacific Linguistics, 2003. 113-144.

LaPolla, Randy J. "On the Logical Necessity of a Cultural and Cognitive Connection for the Origin of all Aspects of Linguistic Structure." Language Structure and Environment: Social, Cultural and Natural Factors. Ed. Rik De Busser and Randy J. LaPolla, 2015. Amsterdam: John Benjamins, 31-44.

Levinson, Stephen C. "From Outer to Inner Space: Linguistic Categories and Non-Linguistic Thinking." Language and Conceptualization. Ed. Jan Nuyts and Eric Pederson. Cambridge: CUP, 1997. 13-45.

Levinson, Stephen C. "On the Human 'Interaction Engine” Roots of Human Sociality: Culture, Cognition and Interaction. Ed. Nick J. Enfield and Stephen C. Levinson. Oxford: Berg, 2006. 39-69.

Mackenzie, J. Lachlan. "A First History of Functional Grammar.” History of Linguistics 2014: Selected Papers from the 13th International Conference on the History of the Language Sciences (ICHoLS XIII), Vila Real, Portugal, 25-29 August 2014. Ed. Carlos Assunçáo, Gonçalo Fernandes and Rolf Kemmler. Amsterdam: John Benjamins, 2016a. 233-246.

Mackenzie, J. Lachlan. “Dynamicity and Dialogue: Perspectives from Functional Discourse Grammar." English Text Construction 9.1 (2016b): 56-76.

Moutaouakil, Ahmed. "On the Layering of the Underlying Clause Structure." Complex Structures: A Functionalist Perspective. Ed. Betty Devriendt, Louis Goossens and Johan van der Auwera. Berlin: Mouton de Gruyter, 1996. 201-227.

Roulet, Eddy, Laurent Filliettaz, and Anne Grobet. Un Modèle et un Instrument d'Analyse de l'Organisation du Discours. Bern: Lang, 2001.

Scott-Philipps, Thom. "Nonhuman Primate Communication, Pragmatics, and the Origins of Language." Current Anthropology 56.1 (2015): 56-80. 
